\title{
KERAGAMAN SERANGGA PADA BUDIDAYA Brachiaria mutica DAN POTENSI REVITALISASI LAHAN DI BAWAH KANOPI KELAPA
}

\author{
Laurentius J. M. Rumokoy 1,2), Constatyn Sumolang1), Ivonne Maria Untu1), dan Wisje Lusia Toar ${ }^{1)}$ \\ 1)Fakultas Peternakan Universitas Sam Ratulangi, Manado 95115 \\ 2) Program Studi Entomologi Pascasarjana Universitas Sam Ratulangi \\ e-mail:wisje_toar@unsrat.ac.id
}

\begin{abstract}
ABSTRAK
Penelitian observasi ini bertujuan untuk mencari tahu kondisi lahan kelapa yang berpotensi direvitalisasi. Secara simultan penelitian ini memiliki tujuan lain untuk mencari tahu keragaman serangga di lokasi budidaya Brachiaria mutica di bawah kanopi pohon kelapa. Metode yang digunakan dalam studi ini terbagi dalam dua tahap, pertama observasi keragaman serangga dilakukan pada lokasi budidaya $B$. mutica di bawah kanopi kelapa dilakukan di Sentrum Agraris Lotta (SAL), tahap kedua adalah survei lapangan menyangkut level kualitas lahan di bawah areal tanaman kelapa di daerah perbatasan Manado dan Minahasa Utara. Hasil penelitian menunjukkan bahwa ada enam ordo dan 10 famili serangga dengan indeks keragaman sebesar 0,323 SWI dengan pola interaksi positif antara serangga-serangga dengan $B$. mutica yang ditanam di bawah tanaman kelapa. Tedapat 37,5\% lahan kelapa yang tergolong Q3. Kondisi kualitas lahan terbanyak pada level Q3 dan Q2 menunjukkan bahwa upaya revitalisasi dibutuhkan untuk dapat memaksimumkan lahan di bawah kanopi kelapa. Dengan demikian dapat disimpulkan bahwa upaya revitalisasi pemanfaatan lahan di bawah kanopi tanaman kelapa perlu dilakukan dengan mempertimbangkan berbagai kondisi lahan dan peranan serangga yang berinteraksi dengan tanaman budidaya tersebut.
\end{abstract}

Kata kunci interaksi serangga, Brachiaria mutica, revitalisasi, lahan kelapa

\section{INSECT DIVERSITY IN BRACHIARIA MUTICA CULTIVATION AND THE POTENTIAL OF LAND REVITALIZATION UNDER COCONUT CANOPY}

\begin{abstract}
The purpose of this study was to observe the importance of revitalizing land use under the coconut canopy which has a less productive tendency by cultivating forage such as Brachiaria mutica by paying attention to interactions with the environment, especially with insects. The method used in this study is divided into two stages: the first is the observation of insect diversity in B. mutica under the coconut canopy, located at Sentrum Agraris Lotta (SAL), and the second stage is a field survey regarding the level of land quality in under coconut plantations in the border area between Manado City and North Minahasa regency. The results in the first step showed that there were six orders and 10 insect families with a diversity index of 0.323 SWI with a positive interaction pattern between the insects and $B$. mutica under coconut trees. There are $37.5 \%$ of coconut land that is classified as Q3. The most land quality conditions at the Q3 and Q2 levels indicate that revitalization efforts are needed to maximize the land under the coconut canopy. We concluded that efforts to revitalize land use under the coconut canopy need to be done by considering various land conditions and the role of insects that interact with these cultivated plants.
\end{abstract}

Key words: insect interaction, Brachiaria mutica, revitalization, coconut plantation

\section{PENDAHULUAN}

Ketersediaan produksi hijauan makanan ternak secara kontinyu menjadi salah satu faktor penentu dalam mengembangkan peternakan ruminansia, namun tidak jarang keterbatasan lahan untuk menjadi kendala untuk melakukan budidaya hijauan makanan ternak. Kondisi lahan di bawah pohon kelapa yang kurang produktif dapat menjadi suatu pilihan untuk mengatasi hal ini. Oleh sebab itu revitalisasi lahan di bawah pohon kelapa ke arah peningkatan ketersediaan produksi hijauan makanan ternak penting dilakukan. Sejalan dengan upaya tersebut, keragaman serangga di bawah areal budidaya tanaman kelapa perlu ditelusuri agar dapat memberi gambaran sebagai salah satu bio indikator. 


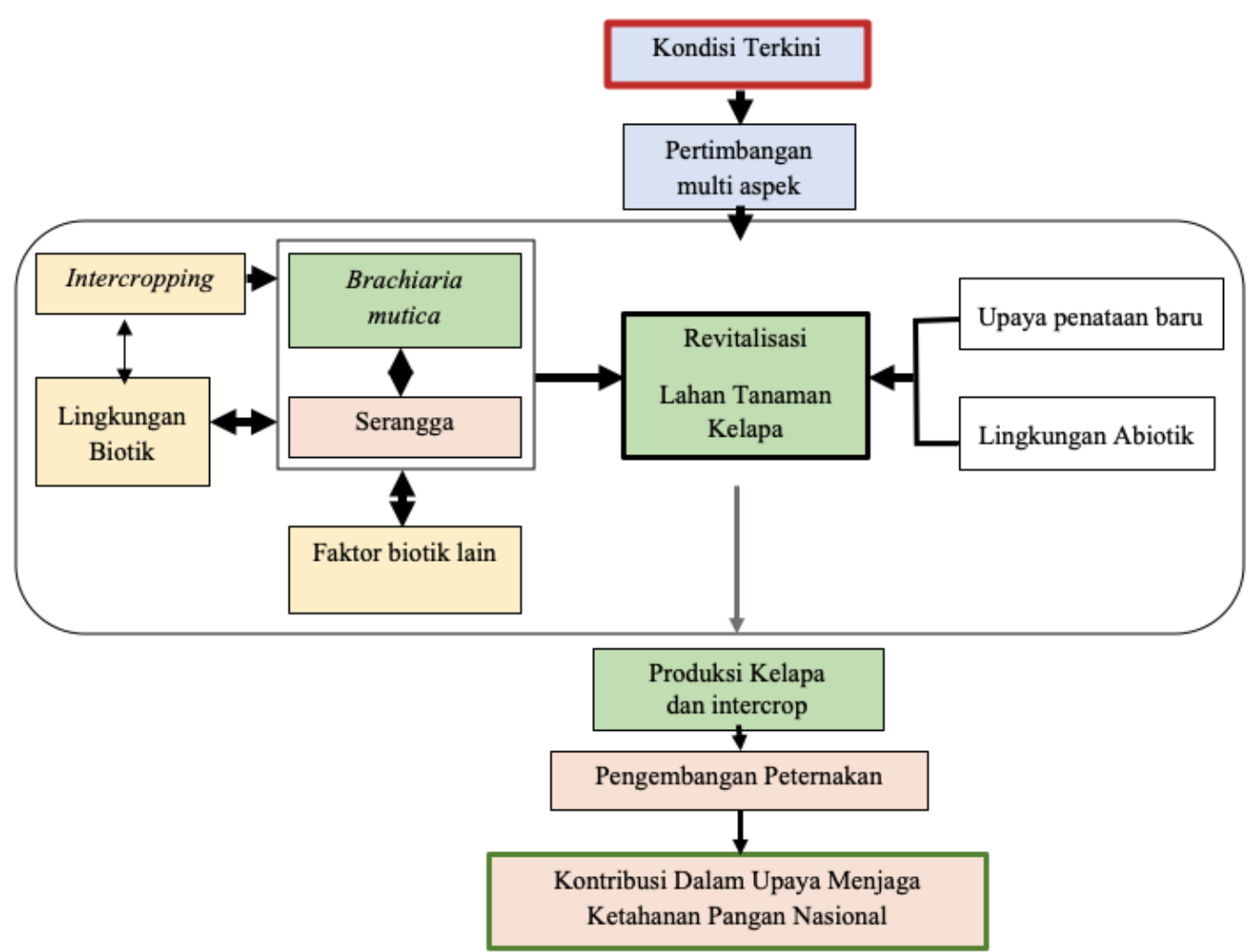

Gambar 1. Diagram Kaitan Berbagai Aspek Dalam Merevitalisasi Lahan Tanaman Kelapa

Iklim tropis basah di Indonesia dengan curah hujan yang cukup tinggi mendukung pertumbuhan vegetasi yang beraneka ragam termasuk berbagai jenis tanaman hijauan makanan ternak juga mudah tumbuh. Sejalan yang dikemukakan Surmaini et al. (2015), potensi iklim ini dapat berpengaruh pada sistem pertanian, yang dalam studi kami menyangkut pengelolaan dan pengembangan budidaya tanaman hijauan makanan ternak sehingga dapat mendukung penyediaan produksi hijauan guna menyiapkan dan memenuhi ketersediaan hijauan pakan ternak ruminansia maupun ternak pseudo-ruminansia.

Berbagai tanaman hijauan dapat dikembangkan untuk tersebut antara lain Brachiaria mutica yang memiliki kemampuan untuk beradaptasi dengan berbagai jenis tanah dan kondisi lingkungan termasuk pada areal atau lahan di bawah kanopi kelapa (Sumolang et al., 2020; Rumokoy et al., 2014; Purwanti et al., 2015). Revitalisasi yang dimaksud di atas dapat dipertimbangkan berdasarkan berbagai kondisi lahan tersebut. Gambar 1 di bawah menunjukkan berbagai aspek yang berperan dalam pengambilan keputusan untuk melakukan penataan kembali fungsi lahan tersebut. Kondisi terkini lahan menjadi landasan pertama untuk pengembangan fungsi lahan. Aspek lain misalnya terkait efisiensi anggaran pengelolaan. Pengembangan hijauan seperti $B$. mutica untuk ternak dapat menjadi pilihan jika disesuaikan dengan hal tersebut, karena tidak membutuhkan anggaran besar.
Lahan di bawah naungan kelapa yang selama ini hanya ditumbuhi gulma dapat direvitalisasi dengan melakukan penanaman hijauan makanan ternak sebagai tanaman intercropping secara produktif dengan penataan yang teratur dan kontinyu.

Pengembangan hijauan makanan ternak sebagai tanaman sela pohon kelapa perlu ditata sedemikian rupa agar dapat berinteraksi dengan berbagai faktor biotik seperti serangga maupun faktor biologik lain yang terdapat di lingkungan sekitar tanaman kelapa itu sendiri sehingga dapat mempertahankan suatu ekosistem yang mendukung produksi tanaman kelapa itu sendiri serta keberadaan berbagai jenis tanaman lain di sekitar lahan perkebunan tersebut secara terintegrasi. Serangga memiliki berbagai peran dalam suatu ekosistem. Pada situasi dimana ekosistem dimana kehidupan serangga secara kolektif ataupun hanya satu atau beberapa jenis terganggu secara signifikan maka dapat berakibat munculnya suatu ketidak seimbangan populasi dari beberapa species tertentu.

Pengembangan pakan ternak untuk ruminansia dan pseudo ruminansia dapat berfungsi untuk memberi kotribusi dalam upaya menjaga stabilitas stok pangan nasional dalam situasi pandemi Covid-19 yang sedang melanda dunia saat ini ataupun dalam mengantisipasi situasi seperti ini untuk masa mendatang. 


\section{MATERI DAN METODE}

Observasi ini dibahagi dalam dua bagian. Pertama untuk mendeteksi keragaman serangga pada lahan di bawah pohon kelapa. Pada bagian kedua dilakukan observasi mengenai kondisi lahan budidaya tanaman kelapa yang dilakukan pada 24 lokasi. Bagian pertama deteksi keragaman serangga dilakukan di areal pertanian Sentrum Agraris Lotta (SAL) terletak di Lotta-Pineleng Kabupaten Minahasa. Kegiatan ini meliputi koleksi serangga yang beraktivitas di tanah dan pada bagian tanaman Brachiaria mutica yang ditanam di bawah kanopi kelapa yang berumur sekitar 30 tahun. Koleksi sampel serangga dilakukan pada 2 transect line dengan formasi zig-zag. Setiap baris dibuat 5 titik A untuk titik koleksi serangga ditanah dan 5 titik B untuk koleksi serangga pada bagian daun dan batang $B$. mutica. Penempatan pada baris pertama yaitu dimulai dari titik $\mathrm{A}_{1}$ kemudian titik $B 1_{1}$ secara berurutan dan selang-seling dengan jarak 1 meter dari satu titik ke titik berikutnya hingga pada titik $\mathrm{A}_{5}$ dan diakhiri titik $\mathrm{B}_{5}$. Pada baris kedua dimulai dari titik $\mathrm{B} 2_{1}$ kemudian titik $\mathrm{A} 2_{1}$ hingga titik $\mathrm{B}_{5}$ dan diakhiri titik A2 ${ }_{5}$ Keliling lokasi penangkapan dilengkapi dengan pagar pembatas untuk menghindari hewan domestik masuk ke lokasi tersebut survei.

Koleksi serangga yang beraktivitas pada bagian tanaman B. mutica dilakukan menggunakan alat penangkapan yaitu swing net-trap berdiameter $30 \mathrm{~cm}$ dengan panjang $40 \mathrm{~cm}$ dilakukan dengan cara mengayun pada serangga yang dapat terbang. Serangga yang tertangkap ini dimasukkan pada botol koleksi. Koleksi serangga yang beraktivitas di tanah dilakukan dengan menggunakan pitfall trap yang ditempatkan pada 10 titik (titik A) di tanah. Sumur perangkap dititik pengkapan selama $1 \times 24$ jam dengan menggunakan gelas plastik yang berisi alkohol 70\% sebanyak $60 \mathrm{ml}$ yang ditambahkan asam asetat sekitar 0,05 ml. Setelah serangga diperoleh di lapangan dilanjutkan dengan identifikasi serangga.

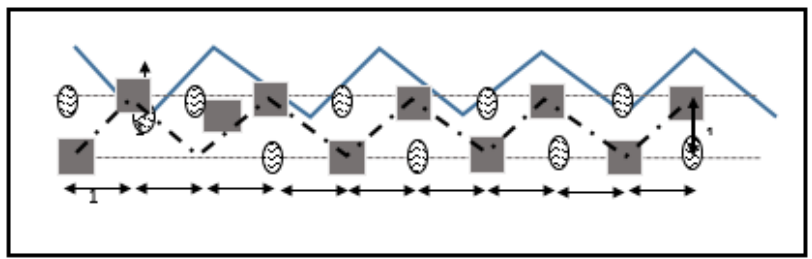

Gambar 2. Skema Titik Pengambilan Sampel Serangga pada Area Budidaya B. Mutica di Bawah Pohon Kelapa

Titik A simbol 8 adalah titik penangkapan serangga di tanah pada penanaman $B$. mutica

Titik B simbol $\square$ adalah titik penangkapan serangga di atas tanah pada bagian $B$. mutica
Keanekaragaman serangga yang berada disekitar pertanaman B. mutica dihitung berdasarkan jumlah individu dalam setiap famili serangga yang teridentifikasi dihitung menggunakan Indeks Keanekaragaman Shannon-Wiener (Spelleberg dan Fedor, 2003), yaitu sebagai berikut:

$$
\mathrm{H}^{\prime}=-\sum_{i=1}^{s}(P i \ln P i)
$$

Nilai $P i$ diperoleh dari:

$$
P i=\frac{n i}{N}
$$

Keterangan:

adalah Nilai indeks keanekaragaman Shannon-Wiener

$n i$ adalah Jumlah individu setiap spesies (dalam studi ini adalah individu setiap famili)

$N$ adalah Jumlah individu seluruh spesies (dalam studi ini total individu seluruh famili)

ln adalah logaritma natural

Catatan:

Tingkat keanekaragaman tinggi jika nilai $>3,5$

Tingkat keanekaragaman sedang jika $1,5 \leq \geq 3,5$

Tingkat keanekaragaman rendah jika nilai $<1,5$

\section{HASIL DAN PEMBAHASAN}

Jenis-jenis serangga yang terpantau pada intercrop Brachiaria mutica di bawah kanopi kelapa di lokasi pengamatan ditampilkan pada tabel di bawah ini:

Tabel 2. Keragaman Serangga di Bawah Kanopi Kelapa di Sentrum Agraris Lotta

\begin{tabular}{llcll}
\hline \multicolumn{1}{c}{ Ordo } & \multicolumn{1}{c}{ Famili } & Jumlah & \multicolumn{1}{c}{$P i \ln P i$} & Nilai H' \\
\hline Coleoptra & Scarabaeidae & 2 & $-0,016502614$ & \\
& Curculionidae & 2 & $-0,016502614$ & \\
& Coccinellidae & 3 & $-0,023045501$ & \\
Hemiptera & Pyrrhocoridae & 1 & $-0,009224829$ & \\
Isoptera & Termitidae & 5 & $-0,03482191$ & \\
Diptera & Muscidae & 6 & $-0,040249875$ & \\
& Drosophilidae & 1 & $-0,009224829$ & \\
& Stratiomyidae & 12 & $-0,068817493$ & \\
Himenoptera & Formicidae & 672 & $-0,05457128$ & \\
Orthoptera & Acrididae & 8 & $-0,050434117$ & \\
& & & & 0,323
\end{tabular}

Berbagai famili serangga yang terpantau pada lokasi yang diobservasi meliputi enam ordo dan 10 famili. Analisis keanekaragaman serangga yang diperoleh menunjukkan bahwa hasil nilai H' sebesar 0,323 SWI yang menunjukkan tingkat keanekaragaman serangga dilokasi pengamatan tersebut berada pada tingkat sedang. Terpantau bahwa jenis serangga paling dominan yang berinteraksi pada tanaman hijauan B. mutica adalah dari ordo Himenoptera yaitu dari famili Formicidae dan diikuti oleh ordo 

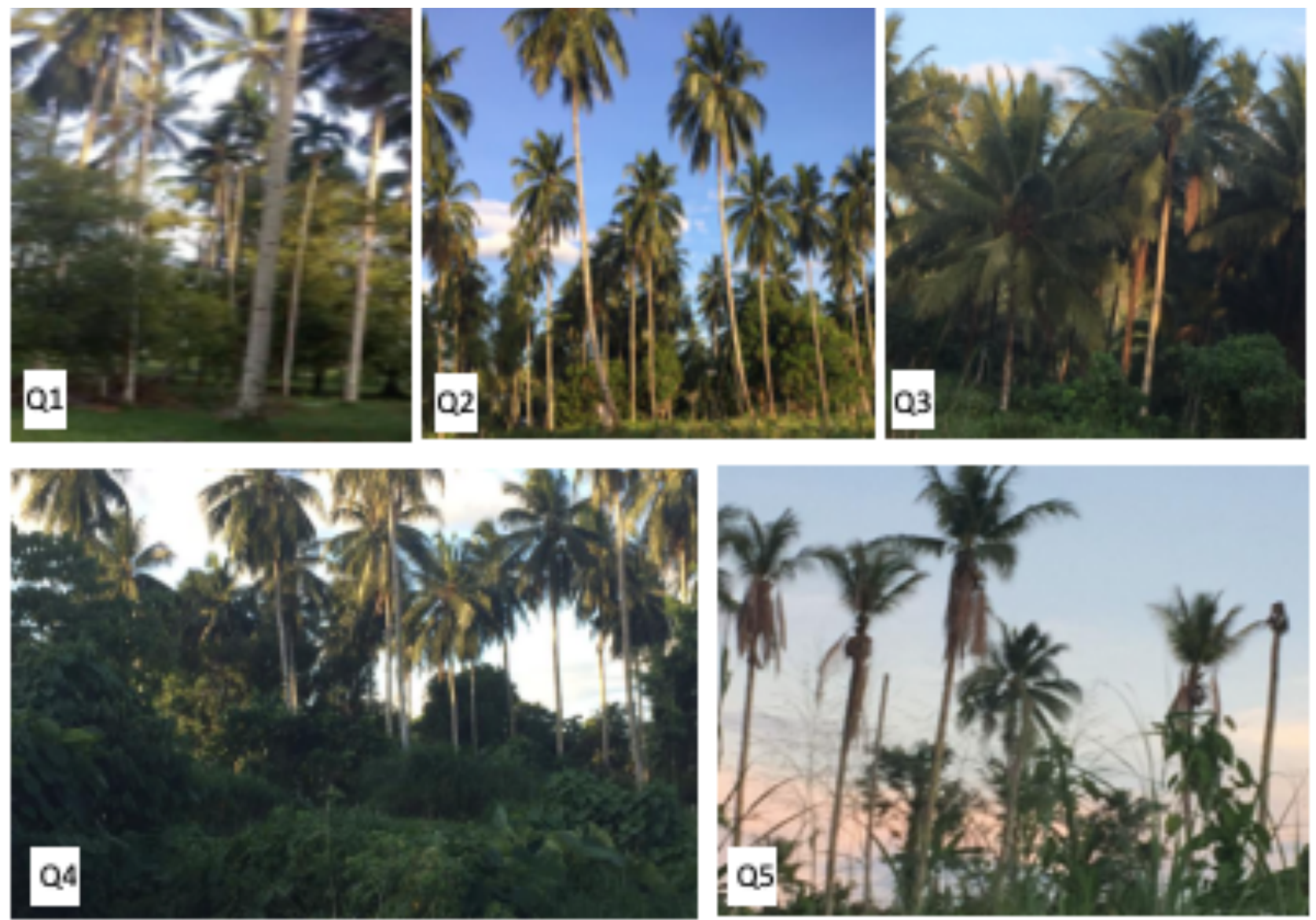

Gambar 3. Gambar Contoh Kondisi Terkini Lahan Pertanaman Kelapa di Lokasi Pengamatan (foto diambil pada Juli 2020)

diptera khususnya famili serangga Stratiomyidae dan Muscidae. Ordo orthoptera yang dijumpai selama observasi adalah Acrididae dengan jumlah individu sebanyak 8 ekor. Penurunan angka kelimpahan serangga herbivora dapat meningkatkan jumlah karbon tanah, sebagaimana yang dilaporkan Wright et al. (2014). Keberadaan serangga yang di atas maupun di bawah tanah dapat berefek pada kesuburan tanah (Blue et al., 2011). Serangga dalam tanah beraktivitas untuk deposisi telur maupun memperoleh makanan dari bahan organik. Efek dari aktifitas tersebut yaitu dapat mempercepat proses degradasi bahan organik yang berdampak pada kesuburan tanah dan pertumbuhan tanaman kelapa disekitarnya. Di sisi lain investasi serangga pada tanaman kelapa dapat mengakibatkan gangguan pada pertumbuhan dan produksi kelapa itu sendiri (Shameer et al., 2018).

Keragaman serangga penting untuk menjaga keseimbangan lingkungan yang ada di sekitarnya. Sebagian serangga beraktifitas sebagai predator serangga lain pada tanaman yang dibudidayakan, sementara sebagian hanya menjadikan sebagai tempat singgah ataupun berlindung. Ketika keseimbangan ekosistem pada area tersebut terganggu maka dapa mengakibatkan aktifitas dengan pola interaksi simbiosis parasitisme akan menjadi lebih tinggi yang

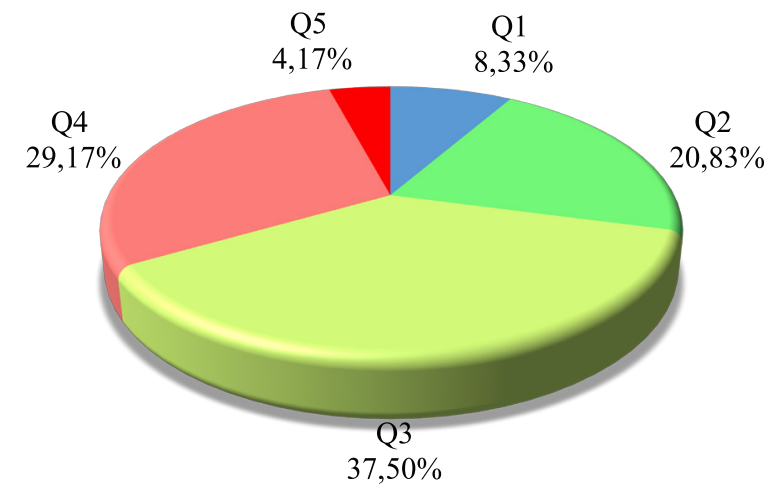

Gambar 4. Presentasi Kondisi Lahan Pertanaman Kelapa di Lokasi Survei

dapat mengganggu kehidupan dan produksi tanaman kelapa serta tanaman-tanaman lain disekitarnya.

Kondisi terkini lahan budidaya kelapa yang disurvei terbanyak adalah menggambarkan kondisi level Q3 yaitu sebesar 37,5\%, diikuti kondisi lahan kelapa Q4 sebanyak 29,17\%, kemudian Q2 berjumlah 20,83\% dan level kondisi Q5 sebesar 4,17\% sebagaimana yang digambarkan dengan diagram lingkaran pada Gambar 4. Data ini menggambarkan bahwa kondisi lahan di bawah kanopi pada umumnya masih perlu ditata karena dan budidaya tanaman sela masih kurang 
terurus, bahkan angka yang cukup penting untuk Q4 (29,17\%) untuk lahan dibawah pepohonan kelapa tidak terlihat tanaman sela karena diselimuti oleh tumbuhan gulma.

Peranan ekologis budidaya hijauan makanan ternak pada pertanaman kelapa antara lain dapat mendukung dalam menjaga keragaman hayati termasuk keragaman serangga yang dapat berdampak pada budidaya tanaman disekitarnya (Montañez dan Amarillo-Suárez, 2014). Apabila lahan pertanian seperti ini yang terdapat di berbagai daerah direvitalisasi untuk penanaman hijauan pakan ternak maka akan dapat menyerap tenaga kerja lapangan serta menunjang pengembangan peternakan ruminansia seperti sapi dan kambing disamping ternak pseudoruminansia seperti kuda dan aneka ternak lain seperti kelinci. Pemenuhan hijauan pakan berkualitas pada ternak akan dapat membantu tubuh ternak tersebut sehat dan mampu menghasilkan antibodi untuk menangkal agen patogen dari lingkungan (Rumokoy dan Toar, 2014). Revitalisasi lahan di bawah naungan kelapa dengan penanaman hijauan berkualitas dapat diarahkan untuk pengembangan peternakan secara terintegrasi dan dapat meningkatkan produktifitas ternak serta pendapatan petani (Priyanti, 2007).

\section{SIMPULAN DAN SARAN}

Keragaman serangga pada lokasi observasi berada pada level sedang. Keberadaan serangga penting dipertahankan untuk menjaga keseimbangan ekologis khususnya dilolkasi budidaya Brachiaria mutica di bawah kanopi kelapa sebagai tanaman intercrop. Budidaya hijauan ini dapat diterapkan pada revitalisasi lahan kelapa untuk membantu menjaga keberlanjutan keseimbangan sistem ekosistem. Sistem pertanian semacam ini dapat dikembangkan dengan sistem pemeliharaan terintegrasi ternak-padang penggembalaan ternak ruminansia.

Penelitian ini masih perlu dilanjutkan pada skala wilayah yang lebih besar agar semakin mendapat informasi yang lebih menyeluruh untuk revitalisasi lahan di bawah kanopi kelapa sehingga produksi pangan dan kesejahteraan petani dapat terus ditingkatkan.

\section{DAFTAR PUSTAKA}

Blue, J. D., L. Souza, A.T. Classen, J.A. Schweitzer, dan N.J. Sanders. 2011. The variable effects of soil nitrogen availability and insect herbivory on aboveground and belowground plant biomass in an old-field ecosystem. Oecologia. 167:771-780

Febrianty, S. D., Sela, R. L. E., dan S. Tilaar. 2015. Identifikasi Faktor-faktor yang Mempengaruhi Perkembangan Wilayah Kota Tidore. SPASIAL, 1(1), 62-69.

Montañez, M.N., and Á Amarillo-Suárez. 2014. Impact of organic crops on the diversity of insects: A review of recent research. Revista Colombiana de Entomología. 40(2):131-142.

Priyanti, A. 2007. Dampak program sistem integrasi tanaman-ternak terhadap alokasi waktu kerja, pendapatan dan pengeluaran rumah tangga petani. Disertasi. Sekolah Pascasarjana. Institut Pertanian Bogor.

Purwantari, N. D., B. Tiesnamurti, dan Y. Adinata. 2015. Ketersediaan sumber hijauan di bawah perkebunan kelapa sawit untuk penggembalaan sapi. Wartazoa, 25(1), 47-54.

Rumokoy, L. J. M., and W. L. Toar. 2014. The forage production of Brachiaria mutica under coconut tree canopy. Lucrări Științifice-Universitatea de Științe Agricole și MedicinăVeterinară, Seria Zootehnie, 62, 131-134.

Rumokoy, L., and W.L. Toar. 2014. The equine colostrums of milk treatment against pathogenic agent. Scientific Papers Series D. Animal Sciencevol, 52, 174-177.

Sumolang, C., L. Rumokoy, H. Liwe, M. Telleng, and W. L. Toar. 2020. Application of dry-mixmanure layer on production of Brachiaria mutica cultivated in unrestricted sunlight area. Scientific Papers. Series D. Animal Science. Vol. LXIII, No. 2.

Shameer, K. S., M. Nasser, C. Mohan, I.C. Hardy. 2018. Direct and indirect influences of intercrops on the coconut defoliator Opisina arenosella. Journal of pest science. 91(1):259-75.

Spellerberg, I. F., and P. J. Fedor. 2003. A tribute to Claude Shannon (1916-2001) and a plea for more rigorous use of species richness, species diversity and the 'Shannon-Wiener'Index. Global Ecology and Biogeography, 12, 177-179.

Wright, P., M. A. Cregger, L. Souza, N. J. Sanders, and A. T. Classen. 2014. The effects of insects, nutrients, and plant invasion on community structure and function above and belowground. Ecology and evolution. 4(6):732-42. 